\title{
Pembelajaran Keterampilan Berbicara di Kelas IV Sekolah Dasar
}

\author{
Nur Azimatul Ummah ${ }^{1}$, Syamsul Ghufron ${ }^{2}$, Suharmono Kasiyun $^{3}$, Dewi Widiana Rahayu ${ }^{4}$ \\ ${ }^{1,2,3,4}$ Universitas Nahdlatul Ulama Surabaya \\ e-mail: ${ }^{1}$ nurummah98@gmail.com, ${ }^{2}$ syamsulghufron@unusa.ac.id, ${ }^{3}$ suharmono@ unusa.ac.id, \\ 르wiwidiana@unusa.ac.id

\begin{tabular}{ccc}
\hline Diterima & Direvisi & Disetujui \\
$22-06-2020$ & $25-07-2020$ & $31-08-2020$ \\
\hline
\end{tabular}

\begin{abstract}
Abstrak - Tujuan umum penelitian ini adalah untuk mendeskripsikan pembelajaran keterampilan berbicara siswa di kelas IV sekolah dasar. Adapun tujuan khusus penelitian ini diperinci dalam tiga hal yakni: (1) mendeskripsikan keterampilan berbicara siswa, (2) mendeskripsikan hambatan dalam keterampilan berbicara, dan (3) solusi guru. Jenis penelitian ini merupakan penelitian kuantitatif dan kualitatif. Teknik pengumpulan data berupa teknik tes dan wawancara. Instrument penelitian ini adalah tes kinerja dan rubrik penilaian keterampilan berbicara serta pedoman wawancara. Populasi dalam penelitian ini adalah siswa kelas IV SDN Keboansikep 01 Gedangan Sidoarjo yang terdiri atas kelas A, B, dan C yang berjumlah 90 orang serta guru kelas IV. Sample penelitian ini adalah kelas IV B yang berjumlah 30 siswa. Teknik pengambilan sample berupa teknik random sampling. Teknik analisis data dalam penelitian ini adalah deskriptif kuantitatif yang diwujudkan dalam bentuk tabel distribusi frekuensi dan statistik deskriptif. Hasil penelitian menunjukkan bahwa keterampilan berbicara siswa kelas IV B di SDN Keboansikep 01 Gedangan Sidoarjo masih tergolong rendah. Berdasarkan hasil tes menunjukkan bahwa 76\% siswa tidak memenuhi batas KKM (skor 75). Adapun hambatan siswa dalam keterampilan berbicara yakni, (1) sulitnya siswa dalam mengeluarkan ide, (2) sulitnya siswa dalam memilih kata, dan (3) kurangnya percaya diri siswa. Solusi yang diberikan guru dalam mengatasi hambatan yang dialami siswa meliputi (1) memberikan motivasi kepada siswa, (2) membuat pembelajaran kreatif dan inovatif, dan (3) memberikan reward kepada siswa.
\end{abstract}

Kata kunci : keterampilan berbicara siswa, hambatan, solusi

\begin{abstract}
The general objective of this research is to describe the learning of students speaking skills in grade IV elementary school. The specific objectives of this study are detailed in three ways namely: (1) describing students speaking skills, (2) describing obstacles in speaking skills, and (3) teacher solutions. This type of research is quantitative and qualitative research. Data collection techniques in the form of tests and interviews techniques. The instrument of this study were performance tests and rubrics for speaking skills assessment and interview guidelines. The population in this study were grade IV students at SDN Keboansikep 01 Gedangan Sidoarjo consisting of classes $A, B$, and $C$ totaling 90 students and grade IV teachers. The sample of this study was class IV B, amounting to 30 students. The sampling technique in the form of random sampling technique. Data analysis techniques in this study were frequency distribution tables and descriptive statistics. The results showed that the speaking skills of class IV B students at SDN Keboansikep 01 Gedangan Sidoarjo were still relatively low. Based on the results of the test showed that $76 \%$ of students did not meet the KKM limit (score 75). As for the obstacles of students in speaking skills namely, (1) the difficulty of students in issuing ideas, (2) the difficulty of student in choosing word, and (3) the lack of student confidence. Solutions provided by the teacher in overcoming obstacles experienced by students include (1) providing motivation to students, (2) making creative and innovative learning, and (3) giving rewards to students.
\end{abstract}

Keyword : student speaking skills, obstacles, solution

\section{PENDAHULUAN}

Dalam kurikulum 2013, pembelajaran bahasa Indonesia khususnya di sekolah dasar bertujuan untuk mengembangkan kemampuan siswa dalam memahami serta membuat teks. Kegiatan pembelajaran berbasis teks ini akan melatih kemampuan berkomunikasi siswa melalui teks cerita. Dalam mata pelajaran bahasa Indonesia terdapat empat aspek keterampilan bahasa, yaitu (1) menulis, (2) membaca, (3) berbicara, (4) dan menyimak. Dari keempat aspek tersebut berbicara merupakan aspek yang tidak kalah pentingnya dari aspek yang lain. Namun, berbicara juga bukanlah suatu hal yang mudah untuk dipelajari sendiri perlu adanya latihan serta pembelajaran yang tepat. 
Badan Standar Nasional Pendidikan (BSNP), menjelaskan bahwa standar isi bahasa Indonesia adalah pembelajaran bahasa Indonesia difokuskan untuk meningkatkan kemampuan siswa agar dapat berinteraksi dengan bahasa Indonesia yang baik dan benar, baik secara lisan maupun tulis, serta diharapkan dapat menumbuhkan apresiasi terhadap hasil karya kesastraan manusia Indonesia (Susanto, 2013). Hal ini menunjukkan bahwa standar dari pembelajaran bahasa Indonesia adalah mampu mengembangkan kemampuan berkomunikasi siswa serta menanamkan rasa cinta terhadap karya sastra.

Pada dasarnya mata pelajaran bahasa Indonesia bertujuan agar seseorang memiliki kemampuan bahasa Indonesia yang baik dan benar. Menurut Febriyanto (2019) tujuan utama dari berbicara adalah untuk berkomunikasi agar dapat menyampaikan pokok pikiran secara efektif. Nafi'ah (2018) menyatakan bahwa pembelajaran bahasa Indonesia mengarahkan siswa untuk lebih mengembangkan keterampilan berkomunikasi dengan bahasa Indonesia yang baik dan benar. Adapun tujuan pembelajaran bahasa Indonesia kelas IV SD dalam Buku Tematik Kurikulum 2013 adalah siswa dapat bercerita dengan artikulasi jelas, ekspresif, intonasi tepat, dan penuh percaya diri.

Susanto (2013) mengungkapkan bahwa tujuan pelajaran bahasa Indonesia di SD adalah siswa mampu menikmati serta memanfaatkan karya sastra agar dapat memperluas pengetahuan kehidupan, serta meningkatkan ilmu pengetahuan dan kemampuan bahasa. Jadi pelajaran bahasa Indonesia diharapkan dapat mengembangkan pengetahuan siswa baik dari segi kehidupan maupun ilmu pengetahuan serta kemampuan berbahasa.

Adapun kompetensi dasar dari mata pelajaran bahasa Indonesia untuk siswa kelas IV mengajak siswa agar dapat menyampaikan hasil identifikasi dari sebuah teks secara lisan, tulis maupun visual. Hal ini menunjukkan bahwa mata pelajaran bahasa Indonesia melatih serta mengembangkan kemampuan siswa khususnya dalam berbicara. Dengan begitu siswa akan terbiasa untuk menyampaikan/mengutarakan isi pikirannya melalui berbicara.

Pada realitanya, dalam pembelajaran bahasa Indonesia di sekolah dasar khususnya dalam keterampilan berbicara siswa masih mengalami kesulitan. Siswa sering mengalami kesulitan dalam mengutarakan apa yang ia pikirkan serta kepercayaan diri untuk berbicara di depan umum. Selain itu, masih banyak siswa yang meremehkan mata pelajaran bahasa Indonesia. Hasil wawancara terhadap guru kelas IV di SDN Keboansikep 1
Gedangan Sidoarjo pada tanggal 11 November 2019 menunjukkan keterampilan berbicara siswa kelas IV masih tergolong rendah. Hal ini terjadi karena banyak dari mereka yang masih kesulitan dalam mengolah kata menjadi beberapa kalimat dengan baik dan benar serta beberapa dari mereka masih banyak yang kurang percaya diri untuk dapat berbicara di depan kelas. Jika dipresentasekan jumlah anak yang sudah mampu dalam keterampilan berbicara masih sekitar $60 \%$ dari 30 siswa. Dengan cacatan dari $60 \%$ tersebut, beberapa dari mereka terkadang masih belum lancar dalam berbicara. Hasil pengamatan dan wawancara tersebut sejalan dengan hasil penelitian Azmi (2019) yang menunjukkan bahwa keterampilan berbicara siswa rendah. Hal tersebut disebabkan karena hampir seluruh siswa mengalami kesulitan dalam berbicara dan nilai rata-ratanya masih belum memenuhi batas KKM, Ustari et al. (2019) mengungkapkan bahwa kemampuan berbicara siswa masih ditahap yang cukup, kurang serta masih ditemukan siswa yang masih gugup ketika berbicara, Said (2019) menyimpulkan dalam pengamatannya menunjukkan $75 \%$ siswa belum tuntas dalam nilai KKM, dan (Ekaningtyas, 2018) yang menujukkan dalam pratindakannya bahwa keterampilan berbicara siswa masih rendah. Hal tersebut dikarenakan nilai rata-rata siswa yang masih belum memenuhi minimal KKM.

Berdasarkan paparan di atas, penulis tertarik melakukan penelitian dengan judul "Keterampilan Berbicara Siswa Kelas IV Sekolah Dasar Di SDN Keboansikep 1 Gedangan Sidoarjo". Tujuan penelitian ini adalah mendeskripsikan keterampilan berbicara siswa kelas IV SD. Keterampilan berbicara merupakan kegiatan untuk menyampaikan pesan atau informasi kepada orang lain melalui bahasa lisan. Dengan berbicara seseorang mampu mengutarakan isi pikirannya serta dapat memahami apa yang orang lain sampaikan. Asih (2016) mengungkapkan bahwa berbicara adalah kemampuan mengucapkan kata untuk mengekspresikan, menyatakan serta menyampaikan pikiran, gagasan, dan perasaan. Oleh karena itu, jika seseorang dalam menyampaikan informasi melalui bahasa dengan kurang tepat, maka akan mempersulit orang lain memahaminya. Dan menurut Astiningtyas et al. (2019) keterampilan berbicara adalah salah satu bentuk untuk mengungkapkan kata dalam menyampaikan gagasan ataupun pesan. Keterampilan berbicara ini dilatih melalui proses pembelajaran.

Keterampilan berbicara merupakah salah satu aspek bahasa yang perlu dipelajari serta dilatih agar dapat mengembangkan keterampilan berbicara siswa. Antari et al. (2019) mengungkapkan bahwa 
berbicara merupakan tingkah laku yang perlu dipelajari dan dikuasai. Semakin sering melatih keterampilan berbicara maka seseorang dapat terampil dalam berbicara. Ekaningtyas (2018) memaparkan bahwa pengembangan dalam keterampilan berbicara siswa sekolah dasr mencakup berbagai jenis dan bentuk kegiatan berbicara, yaitu: memperkenalkan diri, menceritakan pengalaman, mendeskripsikan benda atau seseorang serta tempat, menyapa orang lain, bercakap-cakap, bermain peran, berdiskusi, membahas isi buku dan lain sebagainya.

Menurut Hermawan \& Waluyo (2019) keterampilan berbicara mempunyai empat bagian pokok materi: 1) dimensi rasional, tujuan dan cakupan, fungsi dan relevansinya dalam berbicara, 2) hakikat berbicara, 3) faktor yang mempengaruhi efektivitas berbicara, 4) pengembangan keterampilan berbicara yang mencakup pengajaran berbicara, dan praktik berbicara dengan berbagai tema. Permana (2015) mengungkapkan bahwa ada beberapa aspek yang harus diperhatikan dalam keterampilan berbicara, yakni (1) kelancaran berbicara, (2) keruntutan berbicara, dan (3) ketangkasan. Hal ini membuktikan bahwa keterampilan berbicara tidak mudah untuk dipelajari, perlu adanya latihan serta pembelajaran yang tepat dalam proses belajar mengajar. Jika hal tersebut dilakukan dengan sebaik-baiknya, maka akan mampu melatih serta mengembangkan keterampilan siswa dalam berbicara.

Dengan mengembangkan keterampilan berbicara seseorang juga dapat meningkatkan kreatifitas dalam berbicara serta akan lebih banyak menambah wawasan pengetahuan. Hal tersebut sesuai dengan Permana (2015) menyatakan bahwa keterampilan berbicara memiliki peran penting dalam lahirnya generasi masa depan yang cerdas, kreatif, kritis dan berbudaya. Hal ini menunjukkan bahwa keterampilan berbicara dapat menumbuh kembangkan seseorang menjadi lebih aktif dan cerdas.

\section{METODE PENELITIAN}

Penelitian ini termasuk dalam jenis penelitian kuantitatif dan kualitatif. Penelitian ini dilaksanakan di SDN Keboansikep 01 Sidoarjo pada siswa kelas IV tahun ajaran 2019/2020. Data yang diambil dalam penelitian ini adalah mengenai keterampilan berbicara siswa, hambatan-hambatan dalam pembelajaran keterampilan berbicara serta solusi dan upaya dalam mengatasi hambatan tersebut. Populasi dalam penelitian ini adalah siswa kelas IV SDN Keboansikep 01 Gedangan Sidoarjo yang terdiri atas kelas A, B, dan $\mathrm{C}$ yang berjumlah
90 siswa serta guru kelas IV. Sample dalam penelitian ini adalah kelas IV B yang berjumlah 30 siswa. Teknik pengambilan sample penelitian ini adalah random sampling yang dilakukan dengan cara undian secara acak.

Teknik pengumpulan data dalam penelitian ini dilakukan dengan dua cara, yang pertama adalah tes yang dilakukan untuk mengukur keterampilan siswa dalam berbicara di sekolah dasar dan tes yang digunakan adalah tes kinerja (performance assessment). Teknik yang kedua adalah wawancara yang dilakukan dengan guru kelas IV B SDN Keboansikep 01 Gedangan Sidoarjo. Wawancara ini dilakukan untuk menggali informasi terkait keterampilan berbicara siswa, hambatan yang dialami siswa serta solusi yang guru sudah terapkan.

Tes kinerja (performance assessment) dilakukan peneliti dengan cara mengajak siswa untuk mengembangkan sebuah sinopsis cerita fiksi menjadi beberapa dialog kemudian mempraktikkannya di depan kelas. Kegiatan ini dilakukan dengan cara berpasang-pasangan agar dapat bertukar dialog. Tes ini juga akan melatih nalar siswa dalam mengembangkan sebuah cerita menjadi sebuah dialog yang dirangkai dengan bahasa mereka sendiri. Adapun langkah-langkah dalam tes kinerja adalah sebagai berikut: (1) menentukan kemampuan yang akan dinilai, (2) membuat kriteria-kriteria pada kemampuan yang akan dinilai, (3) membuat rubrik, dan (4) melakukan penilaian dengan cara melihat performance masing-masing siswa.

Instrument penelitian dalam penelitian ini adalah tes kinerja dan rubrik penilaian keterampilan berbicara yang terdiri dari beberapa aspek/kriteria, aspek-aspek tersebut adalah sebagai berikut: (1) kesesuaian isi pembicaraan, (2) ketepatan runtutan cerita, (3) ketepatan makna keseluruhan cerita, (4) ketepatan kata, (5) ketepatan kalimat, (6) kelancaran (Nurgiyantoro, 2010).

Tingkat capaian kinerja meliputi: 1 (kurang), 2 (cukup), 3 (baik), 4 (sangat baik). Adapun kualifikasi nilai yang diperoleh adalah sebagai berikut: 86-100 (baik sekali), 76-85 (baik), 56-75 (cukup), 0-55 (kurang). Rubrik penilaian ini digunakan untuk mengukur keterampilan berbicara siswa di kelas IV B SDN Keboansikep 01 Sidoarjo. Sedangkan instrument dalam wawancara berupa pedoman wawancara yang terdiri dari (1) Persiapan wawancara meliputi bahan-bahan atau sesuatu yang diperlukan sebelum dilakukan wawancara seperti, nomor kontak narasumber, menyiapkan pertanyaanpertanyaan yang akan disampaikan dan lain sebagainya, (2) Proses wawancara yakni kegiatan yang dilakukan dengan narasumber, dan (3) 
Evaluasi yaitu seperti memeriksa kembali apakah semua pertanyaan sudah dijawab.

Data yang diambil melalui tes kinerja (performance assessment) dianalisis menggunakan tabel distribusi frekuensi. Sedangkan data wawancara dianalisis dengan teknik statistik deskriptif yakni mendeskripsikan data yang sudah diambil. Menurut Arifin (2012) statistik deskriptif atau statistik deduktif adalah statistik yang mempunyai tugas untuk mengumpulkan, mengolah dan menganalisis data, kemudian menyajikan dengan baik.

\section{HASIL DAN PEMBAHASAN}

\section{Keterampilan Berbicara}

Pada tahap pendahuluan diperoleh data terkait kegiatan pembelajaran dalam mata pelajaran bahasa Indonesia, terutama terhadap keterampilan berbicara siswa di kelas IV B. Berdasarkan hasil wawancara terhadap guru kelas IV B pada tanggal 11 November 2019 menunjukkan bahwa siswa dalam keterampilan berbicara masih rendah.

Data hasil penelitian ini adalah tentang keterampilan berbicara siswa yang diambil di kelas IV B SDN Keboansikep 01 Gedangan Sidaorjo dengan cara tes kinerja (performance assessment). Tes kinerja ini laksanakan kepada semua siswa kelas IV B yang berjumlah 30 Orang yang terdiri dari 12 orang siswa perempuan dan 18 orang siswa laki-laki. Di dalam tes ini terdapat beberapa aspek yang dinilai untuk mengetahui tingkat keterampilan berbicara siswa. Berikut adalah hasil skor masingmasing aspek keterampilan berbicara di kelas IV B:

Tabel 1. Hasil Skor Aspek-Aspek Keterampilan Berbicara Siswa Kelas IV B di SDN Keboansikep 01 Gedangan Sidoarjo

\begin{tabular}{|c|c|c|c|c|c|c|c|c|c|}
\hline \multirow{2}{*}{ Subjek } & \multicolumn{6}{|c|}{ Skor Tiap Aspek } & \multirow{2}{*}{ SP } & \multirow{2}{*}{ SM } & \multirow{2}{*}{$\mathbf{N}$} \\
\hline & 1 & 2 & 3 & 4 & 5 & 6 & & & \\
\hline 1 & 2 & 3 & 2 & 2 & 2 & 3 & 14 & 24 & 58 \\
\hline 2 & 2 & 3 & 2 & 2 & 2 & 3 & 14 & 24 & 58 \\
\hline 3 & 3 & 3 & 3 & 3 & 2 & 2 & 16 & 24 & 67 \\
\hline 4 & 1 & 1 & 2 & 3 & 1 & 1 & 9 & 24 & 37 \\
\hline 5 & 1 & 1 & 1 & 2 & 3 & 2 & 10 & 24 & 42 \\
\hline 6 & 1 & 2 & 2 & 3 & 2 & 3 & 13 & 24 & 54 \\
\hline 7 & 3 & 3 & 3 & 2 & 2 & 2 & 15 & 24 & 62 \\
\hline 8 & 1 & 2 & 2 & 3 & 3 & 2 & 13 & 24 & 54 \\
\hline 9 & 3 & 3 & 3 & 2 & 2 & 2 & 15 & 24 & 62 \\
\hline 10 & 3 & 3 & 3 & 2 & 2 & 2 & 15 & 24 & 62 \\
\hline 11 & 3 & 3 & 3 & 3 & 3 & 3 & 18 & 24 & 75 \\
\hline 12 & 3 & 3 & 2 & 3 & 2 & 2 & 15 & 24 & 62 \\
\hline 13 & 3 & 3 & 3 & 4 & 4 & 4 & 21 & 24 & 87 \\
\hline 14 & 2 & 2 & 3 & 3 & 3 & 2 & 15 & 24 & 62 \\
\hline 15 & 3 & 2 & 3 & 4 & 4 & 2 & 18 & 24 & 75 \\
\hline 16 & 1 & 1 & 1 & 3 & 3 & 1 & 10 & 24 & 42 \\
\hline 17 & 2 & 3 & 3 & 4 & 4 & 3 & 19 & 24 & 79 \\
\hline 18 & 2 & 2 & 2 & 3 & 3 & 3 & 15 & 24 & 62 \\
\hline 19 & 1 & 1 & 2 & 2 & 3 & 1 & 10 & 24 & 42 \\
\hline 20 & 3 & 3 & 3 & 2 & 1 & 1 & 13 & 24 & 54 \\
\hline 21 & 3 & 3 & 3 & 4 & 4 & 4 & 21 & 24 & 87 \\
\hline 22 & 4 & 4 & 2 & 2 & 2 & 1 & 15 & 24 & 62 \\
\hline 23 & 4 & 4 & 3 & 2 & 2 & 3 & 18 & 24 & 75 \\
\hline 24 & 1 & 1 & 2 & 2 & 2 & 2 & 10 & 24 & 42 \\
\hline 25 & 2 & 3 & 3 & 4 & 4 & 3 & 19 & 24 & 79 \\
\hline 26 & 3 & 3 & 2 & 2 & 2 & 1 & 13 & 24 & 54 \\
\hline 27 & 3 & 3 & 2 & 2 & 2 & 1 & 13 & 24 & 54 \\
\hline 28 & 2 & 2 & 1 & 2 & 2 & 1 & 10 & 24 & 42 \\
\hline 29 & 1 & 2 & 2 & 3 & 1 & 1 & 10 & 24 & 42 \\
\hline 30 & 1 & 1 & 1 & 3 & 3 & 1 & 10 & 24 & 42 \\
\hline Jumlah & 67 & 73 & 69 & 81 & 75 & 62 & 427 & & 1.775 \\
\hline Rerata & 2,2 & 2,4 & 2,3 & 2,7 & 2,5 & 2 & 14,2 & & 59,1 \\
\hline
\end{tabular}

Keterangan :

Aspek $1=$ Kesesuaian isi pembicaraan 
Aspek 2 = Ketepatan runtutan cerita

Aspek $3=$ Ketepatan makna keseluruhan cerita

Aspek $4=$ Ketepatan kata

Aspek $5=$ Ketepatan kalimat

Aspek $6=$ Kelancaran

$\mathrm{SP}=$ Skor Perolehan

$\mathrm{SM}=$ Skor Maksimal

$\mathrm{N}=$ Nilai

Berdasarkan Tabel 1. di atas, siswa masih kurang mampu dalam keterampilan berbicara. Hal itu terlihat dari rata-rata kelas yang hanya 59,1 dengan keterangan kualifikasi adalah cukup. Adapun hasil data yang menunjukkan bahwa ratarata masing-masing aspek yang tertinggi hanyalah 2,7 yakni dalam aspek ketepatan kata. Sedangkan yang terendah adalah skor 2 yaitu dalam aspek kelancaran. Selain aspek kelancaran, terdapat dua aspek lain yang masih rendah yakni aspek kesesuaian isi pembicaraan dan ketepatan makna keseluruhan cerita. Hal tersebut membuktikan bahwa siswa masih mengalami kesulitan terkhusus terhadap ketiga aspek tersebut. Adapun deskripsi keterampilan berbicara siswa pada tiap-tiap aspek adalah sebagai berikut.

\section{a. Kesesuaian Isi Pembicaraan}

Berdasarkan tes keterampilan berbicara yang sudah dilakukan, masih banyak ditemukan pada siswa kelas IV B di SDN Keboansikep 01 Gedangan Sidoarjo ketika berdialog di depan kelas tidak sinkron dengan isi cerita. Isi pembicaraan mereka dalam berdialog masih kurang sesuai dengan isi cerita yang ada, bahkan ditemukan beberapa dari siswa berdialog di luar cerita yang ada.

\section{b. Ketepatan Runtutan Cerita}

Pada aspek ketepatan runtutan cerita, masih banyak ditemukan siswa yang berdialog tidak sesuai dengan alur cerita. Dalam dialog awal sampai pertengahan cerita sudah banyak yang sesuai dengan alur cerita, namun mulai dari pertengahan dialog masih banyak siswa yang tak sejalan dengan alur cerita yang ada. Di sisi lain masih ada beberapa siswa yang sudah mampu menyelaraskan dialog dengan alur cerita.

\section{c. Ketepatan Makna Keseluruhan Cerita}

Berdasarkan tes kinerja yang sudah dilaksanakan, masih banyak siswa kelas IV B di SDN Keboansikep 01 Gedangan Sidoarjo yang berdialog namun makna yang terkandung dalam dialog tak sejalan dengan inti keseluruhan cerita. Hal itu terlihat ketika mereka berdialog namun isi pembicaraan masih kurang tepat dengan makna keseluruhan dalam cerita. Dampak dari hal tersebut pesan yang terdapat dalam cerita kurang terasa tersampaikan melalui dialog yang dilakukan.

\section{d. Ketepatan Kata}

Pada aspek ketepatan kata, siswa sudah banyak yang mampu memilih kata yang tepat pada saat berdialog. Hal tersebut terlihat ketika mereka berdialog dengan kata yang tepat dan sesuai dengan inti cerita. Kata yang mereka pilih juga merupakan kata yang sering dipakai serta mudah dipahami. Namun, terkadang masih terucap kata-kata dari bahasa daerah yang biasa mereka pakai dalam kegiatan sehari-hari.

\section{e. Ketepatan Kalimat}

Sebagian siswa kelas IV B di SDN Keboansikep 01 Gedangan Sidoarjo sudah mampu membuat kalimat yang tepat dalam berdialog. Namun masih ada beberapa siswa yang kurang tepat dalam membuat kalimat. Kalimat yang mereka utarakan dalam berdialog masih ada yang kurang efektif dan masih sulit untuk dipahami. Hal ini terjadi karena mereka kesulitan dalam mengolahnya menjadi bentuk kalimat yang tepat dan benar.

\section{f. Kelancaran}

Aspek yang terakhir adalan kelancaran, dalam aspek ini masih banyak siswa kelas IV B di SDN Keboansikep 01 Gedangan Sidoarjo yang terlihat kurang lancar dalam berdialog. Beberapa dari siswa masih terlihat kurang percaya diri dan gugup dalam berbicara di depan sehingga membuat mereka kurang lancar dalam berdialog. Di sisi lain, sebagian kecil siswa sudah ada yang mampu dalam aspek kelancaran ini.

Adapun nilai keterampilan berbicara siswa kelas IV B di SDN Keboansikep 01 Gedangan Sidoarjo disajikan pada tabel 2 berikut.

Tabel 2. Distribusi Frekuensi Nilai Keterampilan Berbicara Siswa kelas IV B di SDN Keboansikep 01 Gedangan Sidoarjo

\begin{tabular}{|l|l|l|l|l|}
\hline No. & Skor & Frekuensi & $\begin{array}{l}\text { Frekuensi } \\
\text { Kumulatif }\end{array}$ & $\begin{array}{l}\text { CF } \\
(\%)\end{array}$ \\
\hline 1. & $85-90$ & 2 & 2 & 6,7 \\
\hline 2. & $80-84$ & 0 & 2 & 6,7 \\
\hline 3. & $75-79$ & 5 & 7 & 23,3 \\
\hline 4. & $70-74$ & 0 & 7 & 23,3 \\
\hline 5. & $65-69$ & 1 & 8 & 26,7 \\
\hline 6. & $60-64$ & 7 & 15 & 50 \\
\hline 7. & $55-59$ & 2 & 17 & 56,7 \\
\hline $8 .$. & $50-54$ & 5 & 22 & 73,3 \\
\hline 9. & $45-49$ & 0 & 22 & 73,3 \\
\hline 10. & $40-44$ & 7 & 29 & 96,7 \\
\hline 11. & $35-39$ & 1 & 30 & 100 \\
\hline
\end{tabular}




\begin{tabular}{|l|l|l|l|}
\hline Jumlah & $\mathbf{3 0}$ & $\mathbf{3 0}$ & \\
\hline
\end{tabular}

Berdasarkan Tabel 2, jumlah siswa yang mendapatkan nilai sesuai dengan batas KKM (75 ke atas) adalah 7 orang siswa atau 23,3\%. Adapun jumlah siswa yang nilainya tidak memenuhi batas minimal KKM adalah 23 orang siswa atau 76,7\%. Dengan demikian, dapat disimpulkan bahwa keterampilan berbicara siswa kelas IV B di SDN Keboansikep 01 Gedangan Sidoarjo masih tergolong rendah

\section{Hambatan Keterampilan Berbicara Siswa}

Keterampilan berbicara siswa kelas IV B di SDN Keboansikep 01 Gedangan Sidoarjo rendah terjadi karena adanya beberapa hambatan. Berikut hasil wawancara dengan guru kelas IV B yang dilakukan pada tanggal 30 Mei 2020:

Anak-anak biasanya kurang percaya diri, mengolah kata juga sangat kesulitan maksudnya anak-anak cenderung menyampaikan menggunakan dua bahasa yaitu bahasa Jawa dan bahasa Indonesia.

Berikut adalah beberapa hambatan dalam keterampilan berbicara siswa: (1) kesulitan siswa mengeluarkan ide, (2) kesulitan siswa dalam memilih kata, (3) kurangnya percaya diri siswa.

\section{a. Kesulitan Siswa Mengeluarkan Ide}

Kebanyakan siswa kelas IV B di SDN Keboansikep 01 Gedangan Sidoarjo sulit dalam mengeluarkan ide ataupun pendapat. Kebanyakan dari mereka masih bingung serta sulit untuk dapat mengemukakan ide dan pendapat mereka di depan kelas. Selain itu, sebagian dari siswa masih terlihat ragu-ragu dalam mengungkapkan ide pikirannya. Hal itu terjadi karena kurang terbiasanya siswa dalam mengeluarkan ide pikiran atau pendapat dengan cara berbicara.

\section{b. Kesulitan Siswa dalam Memilih Kata}

Sulitnya siswa kelas IV B di SDN Keboansikep 01 Gedangan Sidoarjo dalam memilih kata. Hal ini terjadi dikarenakan dalam kehidupan sehari-hari mereka sudah terbiasa menggunakan bahasa daerah sehingga dalam pembelajaran siswa menggunakan dua bahasa, yakni bahasa daerah (Jawa) dan bahasa Indonesia. Seringnya menggunakan bahasa daerah membuat mereka seringkali kesulitan dalam memilih kata dengan bahasa Indonesia yang baik dan benar.

\section{c. Kurangnya Percaya Diri Siswa}

Hambatan dalam keterampilan berbicara yang sering terjadi adalah kurangnya rasa kepercayaan diri siswa. Hal ini terjadi disebabkan karena masih banyaknya siswa yang malu-malu ketika berbicara di depan kelas. Selain itu, beberapa dari siswa juga usil menggoda temannya ketika sedang berbicara di depan kelas sehingga membuat teman yang sedang berbicara di depan kelas menjadi kurang percaya diri.

\section{Solusi Guru dalam Mengatasi Hambatan}

Berdasarkan wawancara terhadap guru kelas IV B SDN Keboansikep 01 Gedangan Sidoarjo menunjukkan terdapat beberapa solusi dalam mengatasi hambatan keterampilan berbicara siswa. berikut hasil wawancara dengan guru kelas IV B:

\begin{abstract}
Biasanya saya memberikan semangat pada anak untuk berani membuat pertanyaan/menyampaikan jawaban dengan cara memberi hadiah/memberi tambahan nilai. Kebetulan di kelas IV B kelasnya dibentuk kelompok jadi tiap kelompok harus bisa menyapaikan pendapat.
\end{abstract}

Berikut adalah beberapa solusi guru dalam mengatasi hambatan dalam keterampilan berbicara siswa di kelas IV, yakni: 1) pemberian motivasi, 2) pembelajaran kreatif dan inovatif, dan 3) pemberian reward (penghargaan).

\section{a. Pemberian Motivasi}

Guru kelas memberikan motivasi kepada siswa agar dapat mendorong keberanian siswa dalam melatih keterampilan berbicara. Dengan pemberian motivasi yang guru kelas lakukan terus menerus diharapkan siswa dapat mulai memberanikan dirinya dalam mengungkapkan ide pikirannya. Hal ini membuat adanya pemberian motivasi guru kepada siswa perlu untuk dilakukan.

\section{b. Pembelajaran Kreatif dan Inovatif}

Guru membuat pembelajaran yang kreatif serta inovatif, seperti membentuk siswa menjadi beberapa kelompok dan masing-masing kelompok diajak untuk dapat memberikan pendapat maupun pertanyaan dalam pembelajaran. Jadi setiap kelompok harus memberikan pendapat maupun pertanyaan yang sudah mereka buat. Dengan menerapkan pembelajaran seperti itu tersebut dapat melatih keterampilan berbicara siswa.

\section{c. Pemberian Reward (Penghargaan)}

Guru memberikan reward (penghargaan) berupa tambahan nilai ataupun hadiah kepada siswa/kelompok yang dapat mengungkapkan pendapat, pertanyaan maupun sebuah jawaban. Hal 
ini dilakukan untuk membangun semangat siswa dalam mengeluarkan ide pikirannya. Dengan begitu siswa dapat lebih semangat dan berani dalam mengeluarkan ide pikiran maupun pendapatnya.

Berdasarkan solusi diatas menunjukkan bahwa guru harus memperhatikan dan memberi motivasi pada siswa agar dapat mengembangkan keterampilan berbicara siswa. Selain itu, pembelajaran yang tepat akan dapat mendorong siswa untuk lebih berani dalam berbicara.

\section{PEMBAHASAN}

Dari paparan hasil penelitian di atas terlihat bahwa hasil tes keterampilan berbicara siswa yang dilakukan di kelas IV B di SDN Keboansikep 01 Gedangan Sidoarjo masih banyak skor yang rendah. Hal tersebut terjadi karena adanya hambatanhambatan yang dialami siswa dalam berbicara yakni, sulitnya siswa dalam mengeluarkan ide pikiran, sulitnya siswa dalam memilih kata dan kurangnya percaya diri siswa. Karena itu, dibutuhkan adanya solusi guru dalam mengatasi hambatan tersebut yakni, memberikan motivasi, membuat pembelajaran kreatif serta inovatif dan memberikan reward (penghargaan). Guru harus mampu melakukan tugas yang menjadi tanggung jawabnya sebagai bagian dari kompetensi profesionalnya. Tugas yang dimaksud meliputi mendidik yakni meneruskan dan mengembangkan nilai-nilai hidup, mengajar yakni mentransfer dan mengembangkan pengetahuan, dan melatih yakni mengembangkan berbagai keterampilan pada siswa termasuk keterampilan berbicara (Ghufron, 2015).

Hasil penelitian ini menunjukkan bahwa keterampilan berbicara siswa tergolong masih rendah. Hal itu terlihat dari hasil tes yang menunjukkan bahwa masih banyak siswa yang mendapat nilai yang tidak memenuhi batas KKM (skor 75). Hasil penelitian ini sesuai dengan Azmi (2019) yang menunjukkan bahwa keterampilan berbicara siswa masih rendah. Hal tersebut disebabkan karena hampir seluruh siswa dalam penelitian tersebut mengalami kesulitan dalam berbicara dan nilai rata-rata keterampilan berbicara siswa masih belum memenuhi KKM. Penelitian Ekaningtyas (2018) memperkuat penelitian ini yang menunjukkan bahwa dalam pratindakannya keterampilan berbicara siswa masih rendah. Hal tersebut juga terlihat berdasarkan nilai rata-rata siswa yang masih belum memenuhi minimal KKM. Penelitian Said (2019) juga memperkuat hasil penelitian ini yang menyimpulkan dalam pengamatannya menunjukkan $75 \%$ siswa masih belum tuntas nilai KKM.
Hasil penelitian ini juga menemukan adanya kesulitan dari siswa dalam mengungkapkan ide pikiran mereka melalui berbicara sehingga perlu adanya penanganan yang tepat agar dapat membantu siswa dalam mengembangkan keterampilan berbicara. Hal tersebut diperkuat dengan penelitian Ustari et al (2019) yang menyimpulkan bahwa salah satu peyebab kurang mampunya siswa dalam keterampilan berbicara adalah belum mampunya siswa dalam mengungkapkan pendapat dan pemikirannya.

Berdasarkan hasil-hasil penelitian yang membuktikan rendahnya keterampilan berbicara sehingga dibutuhkan adanya solusi dalam mengatasi hal tersebut. Hasil penelitian ini diperkuat dengan penelitian Antari et al (2019) yang menyimpulkan bahwa keterampilan siswa dalam berbicara dapat meningkat jika dilakukan dengan metode pembelajaran yang tepat yang dapat mengembangkan kemampuan siswa dalam berbicara. Penelitian Floryantini et al (2019) juga memperkuat hasil penelitian ini yang menyimpulkan bahwa keterampilan berbicara siswa dapat dikembangkan serta dilatih dengan model pembelajaran yang tepat sehingga siswa dapat aktif dalam proses pembelajaran.

Penelitian Meylinda (2016) juga memperkuat hasil penelitian ini dengan menyimpulkan bahwa terdapat beberapa solusi dalam mengatasi hambatan dalam keterampilan berbicara siswa, yakni: (1) memperkaya pembelajaran dengan menerapkan strategi dan teknik yang tepat untuk pembelajaran berbicara, (2) memperbaiki buku bacaan sekolah siswa atau membuat media dalam pembelajaran berbicara yang digunakan sebagai rangsangan untuk siswa.

Berdasarkan paparan di atas dapat disimpulkan bahwa dibutuhkan penerapan pembelajaran dengan menggunakan strategi dan metode yang tepat yang dapat melatih serta meningkatkan keterampilan siswa dalam berbicara. Pembelajaran yang kreatif tersebut mampu menarik minat siswa untuk lebih berani dalam mengeluarkan ide pikiran ataupun pendapat mereka.

Hal ini menunjukkan bahwa keterampilan berbicara siswa kelas IV B di SDN Keboansikep 01 Gedangan Sidoarjo merupakan keterampilan yang penting serta perlu dikembangkan di sekolah dasar. Hal ini sejalan dengan pendapat yang dikemukakan oleh Astiningtyas et al (2019) yang mengungkapkan bahwa keterampilan berbicara merupakan salah satu aspek keterampilan yang penting untuk dikembangkan di sekolah dasar.

Adapun kelebihan dari penelitian ini yakni menggunakan metode yang lebih bervariasi dan 
terdapat beberapa solusi guru yang dapat menangani hambatan siswa dalam keterampilan berbicara.

\section{KESIMPULAN}

Berdasarkan hasil tes kinerja (performance assessment) dapat diketahui bahwa, keterampilan berbicara siswa di kelas IV B SDN Keboansikep 01 Gedangan Sidoarjo masih tergolong rendah. Hal ini dibuktikan dengan diperolehnya data yang menunjukkan bahwa $76 \%$ siswa masih belum lulus KKM (skor nilai 75) dalam keterampilan berbicara.

Hal itu timbul karena adanya beberapa hambatan, yaitu: (1) kesulitannya siswa dalam memilih kata dengan bahasa Indonesia yang baik dan benar, (2) sulitnya siswa dalam mengeluarkan ide pikiran atau pendapat melalui berbicara, dan (3) rendahnya tingkat kepercayaan diri siswa untuk berbicara di depan kelas.

Adapun aspek-aspek yang dinilai dalam keterampilan berbicara siswa kelas IV B SDN keboansikep 01 Gedangan Sidoarjo, yakni: (1) kesesuaian isi pembicaraan, (2) ketepatan runtutan cerita, (3) ketepatan makna keseluruhan cerita, (4) ketepatan kata, (5) ketepatan kalimat, dan (6) kelancaran. Hasil penelitian menunjukkan pada semua aspek keterampilan berbicara siswa masih terlihat rendah, namun rata-rata siswa banyak mengalami kesulitan dalam tiga aspek, yakni: kesesuaian isi pembicaraan, aspek ketepatan makna keseluruhan cerita dan kelancaran.

Solusi guru dalam mengatasi hambatanhambatan yang dialami siswa kelas IV B di SDN Keboansikep 01 Gedangan Sidoarjo antara lain: (1) memberikan motivasi kepada siswa agar dapat mendorong keberanian siswa dalam keterampilan berbicara, (2) membuat pembelajaran yang kreatif serta inovatif yang dapat melatih keterampilan berbicara siswa, dan (3) memberi reward berupa nilai tambahan atau hadiah ketika siswa sudah berani mengungkapkan ide pikirannya.

Berdasarkan penelitian yang sudah dilakukan, terdapat beberapa saran yaitu sebagai berikut: (1) siswa harus lebih berani dalam mengungkapkan ide pikiran mereka, (2) untuk guru akan lebih baik jika sering menggunakan pembelajaran yang kreatif serta inovatif, (3) kepada kepala sekolah agar lebih mengajak para guru untuk menerapkan pembelajaran yang kreatif dan inovatif, dan (4) penulis lain, sebelum melakukan penelitian dilihat serta cermati dahulu langkah-langkah untuk melakukan penelitian agar dapat meminimalisir timbulnya hambatan dalam penelitian.

\section{REFERENSI}

Antari, N. M. W., Arini, N. W., \& Sumantri, M. (2019). Pengaruh Model Pembelajaran Word Square Berbantuan Media Gambar Terhadap Keterampilan Berbicara. Jurnal Penelitian Dan Pengembangan Pendidikan, 3(3), 174182.

Arifin, Z. (2012). Penelitian Pendidikan: Metode dan Paradigma Baru. Bandung: PT. Remaja Rosdakarya.

Asih. (2016). Strategi Pembelajaran Bahasa Indonesia (ke-1). Bandung: CV Pustaka Setia.

Astiningtyas, A., Wardani, N. S., \& Prasetyo, T. (2019). Upaya Peningkatan Keterampilan Berbicara Melalui PS-MTTW dalam Pembelajaran Tematik Terpadu kelas IV SD. Jurnal Basicedu (Vol 3). https://doi.org/10.31004/basicedu.v3i1.66

Azmi, S. R. M. (2019). Peningkatan Keterampilan Berbicara Menggunakan Metode Bercerita Siswa Kelas V Sekolah Dasar. Journal of Science and Social Research, II(1), 7-11.

Ekaningtyas, D. P. (2018). Peningkatan Keterampilan Berbicara Menggunakan Metode Sosiodrama. Paedagogie (Vol 13). https://doi.org/10.31603/paedagogie.v13i2.23 68

Febriyanto, B. (2019). Metode Cerita Berantai Untuk Meningkatkan Keterampilan Berbicara Siswa Pada Pembelajaran Bahasa Indonesia. Jurnal Cakrawala Pendas (Vol 5). https://doi.org/10.31949/jcp.v5i2.1388

Floryantini, K. N., Sudana, D. N., \& Sumantri, M. (2019). Pengaruh Model Sfae Berbasis Penilaian Kinerja Terhadap Keterampilan Berbicara Bahasa Indonesia Siswa Kelas V. Mimbar Ilmu (Vol 24). https://doi.org/10.23887/mi.v24i1.17468

Ghufron, S. (2015). Pembelajaran Materi Kebahasaan Berdasarkan Kurikulum 2006 dan 2013 serta Upaya Peningkatan Kompetensi Guru. BASTRA: Jurnal Penelitian Pendidikan Bahasa Dan Sastra, 2(1), 23-32.

Hermawan, A., \& Waluyo, B. (2019). Pelatihan Keterampilan Berbicara Untuk Meningkatkan Kemampuan Berbicara didepan Umum pada Himpunan Mahasiswa Program Studi Pendidikan Bahasa Indonesia Universitas 
Nahdlatul Ulama Blitar Tahun 2019. Briliant: Jurnal Riset Dan Konseptual (Vol 4). https://doi.org/10.28926/briliant.v4i1.276

Meylinda, F. (2016). Pengembangan Media Pembelajaran Keterampilan Berbicara Dengan Program Adobe Flash untuk Siswa Kelas V SD. Jurnal Review Pendidikan Dasar: Jurnal Kajian Pendidikan Dan Hasil Penelitian (Vol 2). https://doi.org/10.26740/jrpd.v2n3.p256-264

Nafi'ah, siti A. (2018). Model-Model Pembelajaran Bahasa Indonesia di SD/MI (ke-1). Yogyakarta: Ar-Ruzz Media.

Nurgiyantoro, B. (2010). Penilaian Pembelajaran Bahasa Berbasis Kompetensi (ke-1). Yogyakarta: BPFE.

Permana, E. P. (2015). Pengembangan Media Pembelajaran Boneka Kaus Kaki Untuk Meningkatkan Keterampilan Berbicara Siswa Kelas II Sekolah Dasar. Profesi Pendidikan Dasar, 2(2), 133-140.

Said. (2019). Penerapan Model Pembelajaran Role Playing Untuk Meningkatkan Keterampilan Berbicara dan Hasil Belajar Bahasa Indonesia Pada Siswa Kelas VI SD 2 Padurenan. Jurnal Ilmiah Kependidikan, 2(1), 9-17.

Susanto, A. (2013). Teori Belajar dan Pembelajaran di Sekolah Dasar. Jakarta: Kencana.

Ustari, K. S., Sumantri, M., \& Laba Jayanta, I. N. (2019). Pengaruh Model Pembelajaran Dramatic Learning Berbantuan Boneka Tangan Terhadap Keterampilan Berbicara. Journal of Education Technology (Vol 2). https://doi.org/10.23887/jet.v2i4.16427 